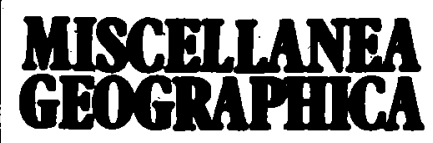

W A R S Z A W A 1988

Jerzy Boryczka, Bogumił Wicik, Małgorzata Gutry-Korycka

\title{
ATTEMPT AT ANALYSIS OF HOLOCENE CLIMATE CYCLES ON THE BASIS OF LAKE SEDIMENTS
}

An attempt at reconstruction and forecast of climate changes (precipitation) in southern Poland was made on the basis of a time trend of sediment accumulation in mountainous lakes. Sedimentation of deposits in those lakes depends mainly on water inflow from precipitation. During intensive precipitation (rain and snow) sand flows to the lake along with water from the direct drainage area. In the core of sediments sampled from below the bottom of Lake Wielki Staw (the Karkonosze mountains), $\mathrm{N}=604$ parts seperated with a thin layer of sand were distinguished. Distances between the sand layers are probably negatively correlated to the sum (frequency) of precipitation. However, an alternative hypothesis may not be excluded that larger distances between sand layers correspond to more abundant precipitation. Intensive precipitation may facilitate sediment accumulation in the lake.

The distances $y_{1}, \ldots y_{N}$ between sand layers occurring at the depth $x_{1}, \ldots$ $x_{N}$ show a sinusoidal variability, which can be described by the following equation:

$$
y=a+b \sin \left(\frac{2 \pi}{T} x+c\right)
$$

where: $T-$ period, $b-$ amplitude, $c-$ phase shift.

Sediment accumulation cycles ( $y$ distances) were determined from the condition of smallest squares, changing the sinusoid parameter (period) $T=1$, $2, \ldots, 8000 \mathrm{~mm}$. Local maximum values of the multiple correlation coefficient $R[y, y(x)]$, verified by the Fischer-Snedecor test $(F)$ correspond to the sought periods of lake sediment accumulation.

The age of lake sediments, determined by the radioactive carbon method $\mathrm{C}^{14}$ at the depth $6.7-6.8 \mathrm{~m}$ is estimated at $5400 \pm 90$ years. (Hel. 1847); thus the trend of their accumulation $\frac{\partial x}{\partial t}$ equals $1.25 \mathrm{~mm} /$ year on the average.

The discovered periods of sediment accumulation $T_{j}(\mathrm{~mm})$, expressed in the long thermal cycles of time, were compared with long-term annual 
precipitation values in southern Poland (meteorological observatory, Wroclaw 1859-1979) and the values of the Laba runoff at the Decin water-gauge $(1851-1968)$ and the Wolf number $(1700-1978)$, which is presented in Table 1.

Table 1

Cycles of lake sedimentation, runoff, precipitation and Sun activity

\begin{tabular}{rrr|r|c|c|c}
\multicolumn{3}{c}{ Lake sedimentation } & \multicolumn{2}{c|}{ Runoff } & $\begin{array}{c}\text { Precipi- } \\
\text { tation }\end{array}$ & $\begin{array}{c}\text { Wolf } \\
\text { number }\end{array}$ \\
\hline$T$ (mm) & $T$ (years) & $F$ & $T$ & $F$ & $T$ & $T$ \\
\hline & & & & & & \\
4 & 3 & 4.45 & 5 & 5.89 & 5 & 11.1 \\
18 & 14 & 3.02 & 10 & 2.77 & 10 & 45 \\
44 & 35 & 3.17 & 15 & 9.87 & 16 & 56 \\
61 & 49 & 4.65 & 22 & 2.69 & 30 & 95 \\
87 & 70 & 2.90 & 30 & 1.52 & 42 & 180 \\
172 & 138 & 3.06 & 47 & 2.14 & 73 & - \\
225 & 180 & 3.50 & 101 & 2.80 & - & - \\
\hline
\end{tabular}

Short cycles (distances between sand layers in the sediments of the lake estimated at 14, 35, 49 years) are similar to the Laba runoff periods: 15,30 , 47 years. The arithmetic mean of two consecutive periods of sediment accumulation 70 and 138 years (104 years) is similar to the 101-year Laba runoff cycle. The observed significant cycle of 70 years of lake sediment accumulation is close to a 73-year cycle of precipitation in Poland. Also the 180 -year cycle of sediment accumulation is similar to a long precipitation period and equal to the period of Sun activity (180 years).

Accumulation of sediments in the high mountainous lake also shows changes in long cycles (Table 2). Some of the cycles do not differ much from periods of organic substances in sediments of another lake in central Poland, i.e. Lake Wikaryjskie near Plock (Boryczka, Wicik 1983).

Table 2

\begin{tabular}{|c|c|c|}
\hline \multicolumn{3}{|c|}{$\begin{array}{l}\text { Long cycles distances } \\
\text { between sand layers in } \\
\text { sediments of the lake } \\
\text { Wielki Staw (Karkonosze } \\
\text { mountains) }\end{array}$} \\
\hline (mm) & $\Gamma($ & $F$ \\
\hline 400 & & 2,40 \\
\hline 820 & & 3,25 \\
\hline 1300 & 1050 & 2,46 \\
\hline 1700 & 1350 & 3,23 \\
\hline $2220^{\circ}$ & 1750 & 2,36 \\
\hline 3300 & 2650 & 10,30 \\
\hline 8000 & 6400 & 164,30 \\
\hline
\end{tabular}


Time trend of sand accumulation in lake sediments was described by the following equation:

$$
y=f(t)=a_{o}+\sum_{j=1}^{m} b_{j} \cdot \sin \left(\frac{2 \pi}{T_{j}} t+c_{j}\right)
$$

where $T_{j}$ - discovered periods.

Amplitudes $b_{j}$ and phase shifts $c_{j}$ were received by minimalizing the square function $E[y-f(t)]^{2}$.

Changes in the distance between sand layers in sediments of lake are described by the following time trend:

$$
\begin{aligned}
y= & 1.675 \sin \left(\frac{2 \pi}{18} x+1.859\right)+1.964 \sin \left(\frac{2 \pi}{44} x-2.707\right)+ \\
& 1.568 \sin \left(\frac{2 \pi}{61} x+1.664\right)+1.150 \sin \left(\frac{2 \pi}{87} x+2.482\right)+ \\
& 1.858 \sin \left(\frac{2 \pi}{225} x-2.826\right)+2.255 \sin \left(\frac{2 \pi}{400} x-2.959\right)+ \\
& 1.327 \sin \left(\frac{2 \pi}{820} x-1.037\right)+1.469 \sin \left(\frac{2 \pi}{1300} x-1.703\right)+ \\
& 0.284 \sin \left(\frac{2 \pi}{1700} x-1.811\right)+3.185 \sin \left(\frac{2 \pi}{2200} x-1.525\right)+ \\
& 6.484 \sin \left(\frac{2 \pi}{3300} x-0.389\right)+16.62 \sin \left(\frac{2 \pi}{8000} x+0.925\right)+20.10
\end{aligned}
$$

where $1 \mathrm{~mm}$ is the unit of sediment thickness $(x)$.

Within the range $-1000 \leqslant x \leqslant 9000$ the curve in Figure 1 is the diagram of the time trend. It is composed of three parts:

$$
\begin{aligned}
6580 & \div 9000 \mathrm{~mm} \text { - reconstruction } \\
0 & \div 6580 \mathrm{~mm} \text { - approximation } \\
-1000 & \div 0 \mathrm{~mm} \text { - forecast }
\end{aligned}
$$

Accuracy of the trend $y=f(x)$ is quite high - the curve is well suited to the results of measurements. Differences between measured distances between sand layers and those calculated from the eqution are distributed similarly to the Gaussian distribution.

$\begin{array}{rr}\text { Range (mm) } & \text { number } \\ <-29.01 & 2 \\ -29.01 \div-19.34 & 9 \\ -19.34 \div-9.67 & 23 \\ -9.67 \div 0.0 & 326 \\ 0.0 \div 9.67 & 195 \\ 9.67 \div 19.34 & 31 \\ 19.34 \div 29.01 & 10 \\ >29.01 & 8\end{array}$




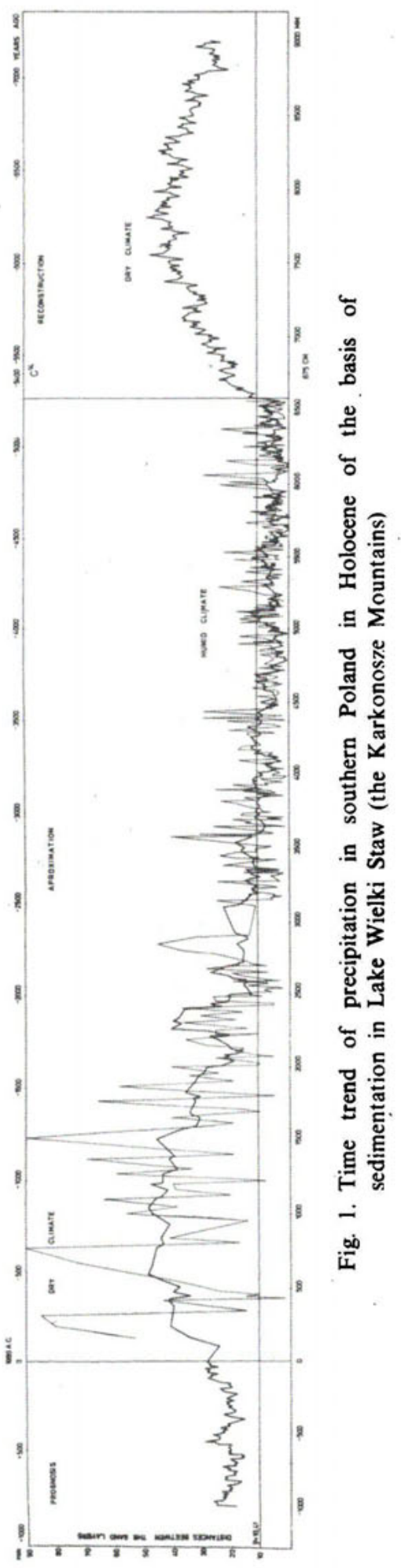


The square mean of the differences $y_{i}=f\left(x_{i}\right)$ is equal to $9.67 \mathrm{~mm}$ and the standard error is $\Delta=9.88 \mathrm{~mm}$. The multiple correlation coefficient is $R=0.703$ and the characteristics of the Fischer-Snedecor test is $F=23.52$. The zero hypothesis $H(\mathrm{R}=0)$, is equivalent to $H\left(b_{1}=\ldots=b_{m}=0\right)$ is groundless at the level of significance of $1 \%$.

Since the trend of sediment accumulation in the lake is $\frac{\partial x}{\partial t}=1.25 \mathrm{~cm} / 10$ years, the calendar time calculation $t$ was introduced, assuming that in $1980 t=0$.

Assuming that the distance between sand layers in sediments of this lake is negatively correlated with the totals of precipitation, epochs were distinguished which differed with respect to climate humidity.

Crossing the graph of the trend function with a straight line $y=\bar{y}=10.41$ $\mathrm{mm}(\bar{y}-$ arithmetic mean), epochs of dry climate $(\bar{y}>10.41 \mathrm{~mm})$ and humid climate $(\bar{y}<10.41 \mathrm{~mm})$ were obtained:

years:

$$
\begin{aligned}
& -7500 \div-5300-\text { dry climate (reconstruction) } \\
& -5300 \div-3100-\text { humid climate } \\
& -3100 \div 0.0-\text { dry climate } \\
& 0.0 \div 1000-\text { dry climate (forecast) }
\end{aligned}
$$

The main minima of the trend curve occurred 4000, 4500, 4900 years ago. Thus a very humid climate occurred at the climate optimum -4000 years ago. This is also the time of a maximum of organic matter in sediments of Lake Wikaryjskie (Boryczka, Wicik .1983).

For the next thousand years a dry climate should be expected $(y>\bar{y})$ and afterwards it could become more humid.

Since the residual of $y_{i}=f\left(x_{i}\right)$ has a distribution similar to normal with parameters $0 . \Delta=9.88 \mathrm{~mm}$, the hypothetic trend is within the confidence range $f(x) \pm 3 \Delta$ with probability of $99.7 \%$

\section{REFERENCES}

B o r y z ka, J., 1984. Model deterministyczno-stochastyczny wielookresowych zmian klimatu (Deterministic and stochastic model of multiperiodical climate changes), Warszawa.

B oryczka J., S to pa-B or yczka, M., 1984. The multiperiodical changes of air temperature in Warsaw, Miscellanea Geographica, Warszawa.

B o ryczka J., Wicik B., 1983. „Holoceńskie cykle klimatu w środkowej Polsce na podstawie statystycznej analizy osadów jexiornych" (Holocene climatic cycles in central Poland on the basis of statistical analysis of lake deposits), Przeglad Geofizyczny. Vol. XXVIII, No. 3-4.

B o r y c z k a J., W i c i k B., G u t r y - K o r y ck a M., 1985. „Poslelednikovyye cikli klimata w yuzhnoi Polshi na fonie staticheskovo analiza otlozhienii w gornykh oxiorakh" (Helocene climate cycles in southern Poland on the basis of a statistical analysis of lake sediments). 
IGCP Project 158, "Palaeoecology and Palaeohydrology of the Balkan Peninsula and Adjacent Areas", Seminar in Bulgaria, Varna 29th Sept. - 4th Oct., 1985.

Wicik B., 1986. Asynchroniczność procesów wietrzenia i sedymentacji $w$ zbiornikach jeziornych Tatr i Karkonoszy w postglacjale. (Asynchronisity of the lakes of the Tatra and Karkonosze Mts in the Post Glacial, Przegląd Geograficzny) Vol. LVIII, No. 4.

Ralska-J as iewiczowa M., Wi cik B., Wi ̨ ck owski K., 187. "Lake Gościąż as a site of annually laminated sediments covering 12000 years", Bulletin of the Polish Academy of Sciences, Earth Sciences, Vol. 35, No. 2.

Pazdur A., Pazdur M., W icik B. W i z ck ow ski K., 1987. "Radiocarbon chronology of annually laminated sediments from the Gościąz Lake", Bulletin of the Polish Academy of Sciences, Earth Sciences, Vol. 35 No. 2. 